\title{
THE ROLE OF METACOGNITION STRATEGY TO ENHANCE READING COMPREHENSION
}

\author{
Fitrani Dinda Fadilah ${ }^{1}$ \\ Natashah Mohd Ridwan ${ }^{2}$ \\ Nurma Dianti Putri ${ }^{3}$ \\ Suhendri Prayoga ${ }^{4 *}$ \\ Muhammad Taufik Ihsan ${ }^{5}$ \\ 1,2,3,4,5 State Islamic University of Sultan Syarif Kasim Riau, Indonesia \\ 11910421261@students.uin-suska.ac.id ${ }^{1)}$ \\ 11910425354@students.uin-suska.ac.id $\left.{ }^{2}\right)$ \\ 11910423006@students.uin-suska.ac.id $\left.{ }^{3}\right)$ \\ 11910413292@students.uin-suska.ac.id ${ }^{*}$ ) \\ muuhammad.taufik.ihsan@uin.suska.ac.id $\left.{ }^{5}\right)$
}

\begin{abstract}
Abstrack
Metacognitive strategy is a learning approach based on John Flavell's Metacognitive notion, which describes Metacognition as an individual's ability to freely govern cognitive processes. Students are taught to organize, manage, and evaluate their learning processes via the use of Metacognitive methods, and their critical and creative thinking abilities are strengthened as a result. This capacity must be mastered in order for pupils to feel responsible for their own learning. Teachers who include processes before, during, and after reading into the process when teaching students' efficient comprehension skills should be conversant with this Metacognitive reading paradigm. In reading, Metacognitive tactics assist pupils in keeping track of their thoughts while they read. Students can use Metacognitive skills to help them become more autonomous learners. Teachers utilize Metacognitive reading skills with their students on a regular basis and expect them to apply them independently as well. Teachers who include the processes before, during, and after reading into the process when teaching students efficient comprehension skills should be conversant with this Metacognitive reading paradigm. In reading, Metacognitive tactics assist pupils in keeping track of their thoughts while they read. Students can use Metacognitive skills to help them become more independent learners. Teachers use Metacognitive reading skills with their students on a regular basis and expect them to apply them independently as well.
\end{abstract}

Keywords: Metacognitive Strategy, Reading, Students

Published by:

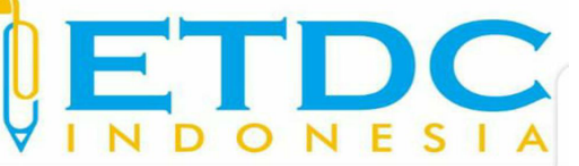

Copyright (C) 2021 The Author (s)

This article is licensed under CC BY 4.0 License

(cc) $\mathrm{BY}$ 


\section{THE ROLE OF METACOGNITION STRATEGY TO ENHANCE READING COMPREHENSION}

\section{Introduction}

Reading is a high-concentration activity that will improve students' conversational skills. It will activate the brain and improve its performance. Reading is a cognitive process or activity that seeks to find various information in writing. This means that reading is a mental process used to comprehend the content of the text read. Reading is thus more than just looking at a collection of letters that have formed words, groups of words, sentences, paragraphs, and discourse; it is also an activity of understanding meaningful symbols/signs/writing so that the message submitted by the author can be accepted by the reader.

According to Tarigan (2008: 7) defines reading as a process carried out and employed by a reader to acquire a message that is delivered by a writer through words and may be seen and recognized by the reader. Reading is also beneficial for language learning. Assuming that students comprehend what they read, the more they read, the better. (Harmer\& Row, 2007: 99) In a nutshell, reading is the activity of deriving meaning from printed words or symbols, as well as how this capacity is applied to recognize, comprehend, and interpret in words.

The quality of the particular instructor is essential to the achievement of foreign language readers. Reading teachers must be passionate about their jobs. They should consider themselves facilitators, supporting each reader in selecting what is best for them. A excellent reading instructor actively teaches pupils on what they should do. Teachers need more than a classroom and procedures to be effective in reading class. Furthermore, Aebersold and Field (1997: 95) argue that in order to become better readers, students must become aware of how they read and what they can do to increase comprehension.

The ability to understand/generate meaning from a text or to connect the text's message to prior knowledge is referred to as comprehension. Reading is done for the sake of understanding, and language plays a big part in that. A reader's reading abilities must be appropriate in order to comprehend a book. According to Snow (2002) states that, reading comprehension is the process of simultaneously extracting and constructing meaning through interaction and involvement with written language. Reading activities, on the other hand, can help students learn English in some ways. For example, students may engage in reading activities to help them learn the language. It is a method of interacting with the text. The most important aspect of the reading process is how students comprehend the text. Meanwhile, Flavell (1979) defines Metacognitive knowledge as "knowledge or beliefs about what factors 
or variables act and interact in what ways to affect the course and outcome of cognitive enterprises." These elements are divided into three groups: person, task, and strategy. Before beginning to read, students must understand how to improve and apply person, task, and strategy. The term "meta" implies "after" or "behind." The act or process of knowing is referred to as cognition. Metacognition is the understanding of what lies behind, supports, or informs a reader's knowledge and viewpoint. perception. When reading, teachers must help their pupils use every possible approach and skill. Teachers must first get a thorough grasp of reading behavior in order to do so. Teachers observe and encourage students' learning processes during class, and they assess the outcomes of students' learning when they talk and respond.

As a foreign language, the English language is not the same and it has distinction especially in reading, reading the English text is not easy and it's different from our main language. Mostly learners faced many difficulties when asked to read an English text, such as: difficulties in vocabulary, the structure, or any item of the language. That's why, many of them feeling frustrated and hard to complete instruction. There are many factors that will give an impact of reading skills, for instance: background experience, thinking ability, language abilities, reading goals, and students' affection like their motivation, attitude and feeling. Those factors have a significant impact on the students' ability to comprehend what they read. (1980, page 20) Comprehension is required for reading. Students should not read the material for an extended period of time in order to gain a thorough understanding of it during the comprehension process. Reading in this manner may not provide the reader with a complete understanding of what he or she is reading, and it is a waste of time. As a result, in all reading courses, students should improve their reading speed and skimming.

Moreover, Iftanti (2012), according to her research despite having formally learned English in school, most EFL students do not have a healthy reading habit. It might be due to a lack of motivation from the instructor or parents at home. Reading habit is a recurring kind of reading practice, implying that the activity must be done on a regular basis. Reading comprehension necessitates familiarity with the material in order to urge kids to read it. People are usually interested in reading when they believe it will be beneficial to them. This is why the topic covered in class should be one that the students believe they require.

One type of strategy, a technique, or approach that can be used in teaching reading is the Metacognition strategy. According to Flavell (1979), Metacognition is significant in the disciplines of reading comprehension and self-control, emphasizing the link between reading comprehension and Metacognition. Furthermore, Zhang and Sheepo (2013, p. 55) note that "Metacognitive techniques are viewed as high order executive abilities that make use of 
knowledge of cognitive processes and comprise an attempt to govern one's own learning through planning, monitoring, and assessing."

As a result, in reading, Metacognitive methods are classified as self-monitoring and selfregulation activities of pupils, allowing them to focus on both the process and the results of reading. To put it simply, using a Metacognitive method, students may predict, monitor, and assess the substance of the text even before they begin to read.

This paper focuses on the theory of Metacognition and its significance in improving students' reading comprehension. It includes a brief review of studies on the development of Metacognition in reading comprehension as well as a brief description of some of the basic ideas of Metacognition. Furthermore, it is intended that the research will lead to future studies on students' knowledge of the reading process, as well as practical ideas for helping students become more aware of and apply reading approaches. As a result, this paper can be utilized as a reference for field research.

\section{Methodology}

This journal was generated by analyzing documents and articles. It is begin with a definition of reading. First, we'll go through the definition of Metacognition, which will be examined using publications and journals. The second is on the reading content, and the third is about Metacognition strategies. All of the resources used in this study were obtained from a range of papers, books, and internet sources.

\section{Discussion}

Reading comprehension is the ability to manage a text, comprehend it's significance, and to consolidate with what the reader definitely knows. Davis (1994) emphasized that knowing the phrases, understanding the definition of a sentence from the context, following the organisation of a section and identifying ancestors and reference materials, drawing conclusions from a text about its contents, identifying the primary concept of a passage, answering questions addressed in a passage, and recognising literary techniques or probabilistic strides are all core abilities vital for effective reading comprehension (discourse-semantics). LaBerge and Samuels (1974) presented a theory of reading comprehension that includes three memory systems: visual memory, phonological memory, and semantic memory. Almost all of the study on Metacognition has been focused on reading learning and effectiveness.

According to Paris, Lipson \& Wixson (1983) reading is active and strategic, because according research in the departments of psychology and education. Paris, Wasik \& Turner, (1991) underlined that self-controlled readers participate in intellectual and metacognitive assignments before to, during, and subsequent to reading.As reported by Pressley \& Afflerbach, 
(1995) they implement "constructively responsive reading," which is reading with a goal in mind and actively generating meaning from a text. Anderson (2002:365) defines Metacognition as the integration of several attentive thinking and reflection processes. His division is made up of five major components: (1) planning and preparing for learning; (2) selecting and implementing learning methods; (3) monitoring strategy usage; (4) coordinating numerous strategies; and (5) assessing strategy use and learning.

Reading comprehension relies heavily on Metacognition. As indicated by metacognitive research, less talented readers don't see the point of reading and on second thought center around word-by-word reading rather than reading for significance. Reading comprehension is influenced by the reader's knowledge, experiences, and intent, as well as the substance and parts of the text and the Circumstance on the other hand setting of reading. Kintsch, (1998) defines perusing understanding is the procedure and item of the concepts conveyed in the text identified with the reader's current information and encounters, just as the psychological portrayal of the text in memory. Metacognitive cycles associated with reading apprehension that contains Metacognitive information and Metacognitive checking and control, as one might expect from the definition of Metacognition. Readers with better Metacognitive abilities can analyze for perplexity or inconsistency, implement a correction technique, such as rereading, linking different bits of the message to each other, searching for subject sentences or rundown sections, and relating flow material to past information. While practising these talents, the readers do not identify them, but when questioned, they can appropriately explain their Metacognitive processes. They know about their own insight and have the perception capacity to investigate, control, and change their own intellectual cycles. Duffy (2009:691) led one of the investigations examined about the discoveries. He examined options in contrast to the coordinated reading example that would give students greater freedom to construct independent reading understanding capacities. The discoveries of this study showed Metacognition as a technique for understanding perception and as a strategy for comprehension education.

\section{Reading Strategy of Metacognitive in Reading Comprehension}

Metacognitive abilities are fundamental for reading achievement. The objective of Metacognitive preparing to further develop readers become more aware of their own thoughts while reading. Educators give express preparing on the utilization of Metacognitive reading strategies that trainees or students can use while reading during guidance. Express guidance of perception procedures starts with an educator plainly introducing and displaying the systems, 
trailed by a conversation regarding when and how a reader should utilize the technique while reading, and ultimately with scaffolded student practice of the strategies while reading. Modeling skills are frequently used by teachers using think-aloud approaches. This educational cycle allows for the progressive transfer or release of responsibilities from instructor to student. Students progressively gain the ability to begin and use that specific method on their own over time. Israel (2007:436) emphasized the cycle is repeated with a different method.Ideally, reading techniques may be grouped into three Metacognitive clusters: (1) organizing, (2) observing, and (3) assessing methods. Prior to reading, arranging techniques are used; for instance, drawing in students' past information to get ready for reading is a guide of an arranging methodology.Besides, looking into a title, picture, realistic, header, or heading may help readers get a feeling of the general design of the material. Readers can likewise see the overall data and construction of the book. Students can analyze their reading material to check whether it has a specific text structure, like circumstances and logical results, question and reaction, or investigate. Defining an objective for reading may likewise be named an arranging strategy.

An assessment of research amalgamations and investigations of informative projects and procedures uncovers that a wide scope of strategies have been proposed as significant for the improvement of reading perception. Nonetheless, most systems attempt to support, screen, or potentially keep up with comprehension and gaining from writing. Brown (1980), for instance, referenced methods, for example, clarifying the destinations of reading; perceiving the significant components of the message; recognition on the fundamental substance; controlling consistent process and decide if perception is happening; investigating and selfaddressing to assess yet on the off chance that objectives are being accomplished; reacting to input when capacity to appreciate disappointments are distinguished; and re-establishing from insecurities and interruptions. Accordingly, Pressley $(2000,2002)$ mentioned: using framework or background information, foreseeing the future, creating poll while reading, building up mental pictures that address the meanings of the text, recognizing significant data, endeavoring to make joins between thoughts in the text, summing up, observing agreement, and settling hardships as they arise.

Metacognitive methods improve readers' capability to build meaning, the Monitor text and reading comprehension, and assess the material they are reading. This Metacognitive reading paradigm, according to Pressley (2006:564), ought to be known to instructors who coordinate previously, during, and in the wake of understanding cycles while showing understudies productive perception abilities. In rundown, Metacognitive reading techniques are isolated into three classifications: arranging (pre-reading), observing (while at the same time 
reading), and evaluating (post-reading), with every class containing a scope of strategies that require readers' Metacognitive handling.

a. Arranging Strategies

Arranging strategies are Metacognitive techniques utilized by readers to help reading cognizance right off the bat in the understanding system (prior to reading). Prior to reading, Metacognitive readers utilize the accompanying arranging systems: (1) drawing in past information; (2) checking on text content; (3) connecting text to text; and (4) relating text to self.

b. Observing systems

Observing systems-which are frequently utilized when reading a text—permit the peruser to focus on significance creation just as cure disappointments in comprehension. Metacognitive perusers utilize the accompanying observing strategies when perusing: (1) evaluating the importance of words; (2) addressing; (3) dissecting; (4) checking; (5) summing up; and (6) looking for key data.

c. Reading assessment systems

In the wake of reading assessment systems that permit the reader to contemplate the text and make an intellectual or emotive evaluation. Metacognitive readers utilize the accompanying appraisal methods in the wake of reading: (1) thinking like the writer; (2) dissecting the text; (3) expecting information use; (4) checking for significance, perceiving when you know and when you don't have the foggiest idea; (5) utilizing and creating mapping, drawing joins between the new and the known, building and enacting foundation information (6) posing inquiries, delivering requests that bring you more profound into the text previously, during, and subsequent to perusing; (7) surveying significance, recognizing what makes a difference most, what merits recalling; (8) inducing, coordinating earlier information with literary data to expect, finish up, make decisions, and decipher; (9) utilizing tactile and passionate pictures to create and grow importance; and (10) orchestrating delivering an advancement of significance by mixing comprehension and information.

\section{Conclusion}

MRS has been proven to be a successful approach of teaching reading comprehension. Before performing the technique, teachers should clearly explain how to carry out the procedures. It is vital for teachers to understand the most effective methods for raising children's motivation to learn to read. Metacognitive strategies boost readers' abilities to construct 
meaning, monitor text and reading comprehension, and analyze the content they're reading. Teachers who combine before-, during-, and after-reading processes while teaching pupils good comprehension abilities should be conversant with this Metacognitive reading paradigm. MRS helps pupils to keep track of their thoughts while reading. MRS encourages students to learn on their own. Teachers regularly teach Metacognitive reading skills to their students, with the idea that they would utilize them independently as well, which may or may not be the case. Teachers are supposed to model Metacognitive abilities, providing help as students learn how to utilize them and gradually lowering that help as students gain independence. MRS appears to help youngsters use appropriate approaches to address their reading challenges, according to one research. MRS teaches youngsters how to stop relying on dictionaries. MRS assists students in locating the core concept, implicit and explicit information, references, and meanings for words.

\section{REFERENCE}

Aebersold, J. \& Field M. (1997). From Reader to Reading Teacher. Cambridge: Cambridge University Press.

Anderson, N. J. (2002). The role of metacognition in second language teaching and learning. ERIC.

Brown, A. L. (1980). Metacognitive development and reading. In R. J. Spiro, B. Bruce \& W. F. Brewer (Eds.), Theoretical issues in reading comprehension (pp. 453-479). Hillsdale, NJ: Erlbaum.

Davis, Frederick B. (September 1944). "Fundamental factors of comprehension in reading". Psychometrika. 9 (3): 185-197.

Duffy, Gerald G. (2009). Explaining Reading: A Resource Four Teaching Concepts, Skills, and Strategies. New York: The Guildford Press.

Flavell, J. H. (1979). Metacognition and Cognitive Monitoring: A new are of cognitive developmental inquiry. American Psychologist, 34 (10), 906- 911.

Harmer, Jeremy. (2007). The Practice of English Language Teaching Fourth Edition. Pearson Longman: Harlow.

Israel, S. E. (2007). Using metacognitive assessments to create individualized reading instruction. Newark, DE: International Reading Association.

Kintsch, W. (1998) Comprehension: A paradigm for cognition. New York: Cambridge University Press.

LaBerge, D., \& Samuels, S. J. (1974). Toward a Theory of Automatic Information Processing in Reading. Cognitive Psychology, 
Nunan, D. (2004). Task-based language teaching. Cambridge, UK: Cambridge University Press.

Pajarwati, D., Mardiah, H., Harahap, R. P., Siagian, R. O., \& Ihsan, M. T. (2021). Curriculum Reform In Indonesia: English Education Toward The Global Competitiveness. ETDC: Indonesian Journal of Research and Educational Review, 1(1), 28-36.

Paris, S. G., Lipson, M. \&Wixson, K. (1983). Becoming a strategic reader. Contemporary Educational Psychology, 8, 293-316.

Paris, S. G., Wasik, B. A. \& Turner, J. C. (1991). The development of strategic readers. In R. Barr, M. L. Kamil, P. B. Mosenthal \& P. D. Pearson (Eds.), Handbook of reading research (Vol. II, pp. 609-640). New York: Longman.

Pressley, M. \&Afflerbach, P. (1995). Verbal protocols of reading: The nature of constructively responsive reading. Mahwah, NJ: Erlbaum.

Pressley, M. (2000). What should comprehension instruction be the instruction of? In M. L. Kamil, P. B. Mosenthal, P. D. Pearson \& R. Barr (Eds.), Handbook of reading research, (Vol. II1, pp. 545-561). Mahwah, NJ: Erlbaum.

Pressley, M. (2002). Comprehension strategies instruction: A turn-of-the-century status report. In C. C. Block \& M. Pressley (Eds.), Comprehension instruction: Research-based best practices (pp. 11-27). New York: Guilford Press.

Pressley, M. (2006). Reading Instruction That Works: The Case for Balanced Teaching. New York: Guilford.

Ridhwan, M., \& Ihsan, M. T. (2018). THE EFFECT OF COMIC STRIPS ON SECONDARY EFL STUDENTS'READING COMPREHENSION AND WRITING ABILITY. EJI (English Journal of Indragiri): Studies in Education, Literature, and Linguistics, 2(2), 4357.

Snow, Catherine. (2002). Reading for Understanding: Toward an R\&D Program in Reading Comprehension. Los Angeles: RAND

Tarigan, Henry Guntur. 2008. Membaca Sebagai Suatu Keterampilan Berbahasa. Bandung: Angkasa. 